development. By March 31, 1948, local education authorities are obliged, with minor exceptions, to submit their schemes of further education to the Ministry. Many of them have already begun, and even the backward authorities will have something to promise, if not to display, by the appointed day.

Further education may henceforth hope to enjoy something better than the status of a lesser mandated territory. But a sentimental ardour for its benefits is not enough. What are especially required during these next few years are practicable schemes, reliable progress reports, and a brisk exchange of ideas. The first number of Further Education reveals a realistic purpose in providing these requirements, and is not afflicted by that sense of piety which so often besets ventures which want to advance human progress. In writing or talking about further education it is better to be hard-boiled than half-baked, and one of the characteristics of this new magazine is its preoccupation with ways and means. Its editor, Mr. J. Mackay Mure, is a fẹrvent educationist, and his management of the paper's policy is an assurance that it will keep both feet on the ground. From the first number, it is plain that he intends to take full advantage of the terms of reference embodied in the paper's title. Further education has as much to do with vocational training as with the pursuit of culture, and the more we can be led to considering them as part of a common way of life the sooner shall we discern their relevance to each other. One final merit of this new monthly must be mentioned, and that is the lively quality of most of its articles. Nowhere has the boll-weevil of jargon made greater ravages than in educational journalism, and it is a welcome relief to find it entirely absent from these pages.

\section{The Ray Society}

THE annual general meeting of the Ray Society, now in its hundred and third year, was held on March 21. During the past year the Society lost by retirement owing to ill-health the services of its two senior officers, Sir Sidney Harmer, president since 1931, and Dr. W. T. Calman, secretary since 1919. Resolutions were passed unanimously thanking them for their distinguished services to the Society. Prof. F. E. Weiss having expressed the wish to retire from the office of honorary treasurer, his resignation was accepted with regret. Mr. A. D. Cotton resigned as vice-president. It was announced that Dr. Ben Dawes' volume on "The Trematoda of British Fishes" is ready for distribution, and, owing to the greatly increased costs of publication, this will form the issue to subscribers for the two years 1944 and 1945 . The volume for 1946 will be Dr. Berrill's volume on "British Tunicates", but unexpected difficulties have caused delay in sending this work to press. A volume on Pennant's travels in Europe, edited by Prof. G. R. de Beer, is, however, nearly ready for press, and other works on a wide variety of subjects relating to the natural history of the British Isles are in active preparation. The following were elected officers and new members of council : President, Prof. G. R. de Beer; Hon. Treasurer, Mr. A. C. Townsend; Hon. Secretary, Dr. Errol I. White; Vice-presidents, Prof. F. E. Weiss, Mr. M. A. C. Hinton, Mr. E. R. Martin and Lieut.-Colonel Seymour Sewell ; Members of Council, Mr. A. H. G. Alston, Dr. J. W. Evans, Mr. H. R. Hewer, Dr. George Taylor and Mr. Brian Vesey-Fitzgerald.

\section{New British Ornithological Magazine}

THE first issue of the new Wild Birds Magazine has appeared as a bi-monthly (until the paper ration increases) under the editorship of Mr. Eric Hardy and published from Friars Lodge, Friars Lane, Richmond, Surrey. There are illustrated articles dealing with bird-life at Manchester sewage farm (L. L. Turner), observations at the Yorkshire Naturalists' Union's new bird ringing and observation station at the Spurn by J. Lord, on a heronry (F. A. Lowe), birds of North Devon (N. V. Allen), Dungeness shingle (R. B. Burrowes), etc., while field notes include the first Lancashire record of the European beeeater (Merops apiaster) in the autumn 1946, and the red-backed shrike using the same nesting site in two successive years. An abnormal immigration of waxwings and great grey shrikes into England during the recent winter is noted.

\section{Industrial Uses of Methane}

A PAMPHLET entitled "Chemicals from Methane", by Dr. J. P. Lawrie (pp. 24. Science Services, Ltd., 255 Russell Court, London, W.C.1, 1947. 3s.), deals with possible uses of methane from natural gas which, it is said, is available in important quantities in Great Britain. It is pointed out that large quantities of carbon black are imported from the United States, much of which is made there from natural gas, and it is suggested that this might well be made from native gas. Coke-oven gas is also rich in methane. Other products which might be obtained from methane, according to patent literature quoted, are hydrogen for ammonia synthesis, acetylene by exposure to an electric arc, methyl chloride by chlorination, hydrogen sulphide by reaction with sulphur, oxidation products such as methanol, formaldehyde, and formic acid, and nitromethane. A short bibliography is given.

\section{Royal Institution}

At the anniversary meeting of the members of the Royal Institution held on May 1, the following officers were elected: President, Lord Rayleigh; Secretary, Prof. A. O. Rankine; Treasurer, Dr. R. E. Slade; Managers, Prof. E. N. da C. Andrade, Mr. M. G. Bennett, Prof. H. V. A. Briscoe, Major W. H. Cadman, Sir John Craig, Dr. C. H. Desch, Sir.Alfred Egerton, Dr. E. V. Evans, Dr. W. Jevons, Colonel E. E. B. Mackintosh, Mr. G. S. W. Marlow, Prof. L. C. Martin, Sir Richard Paget, Sir Clifford Patterson, Sir Geoffrey Taylor; Visitors, Mr. J. J. Abraham, Mr. W. E. Watson Baker, Dr. J. H. Brinkworth, Mr. D. I. Duveen, Mr. F. P. Dunn, Mr. P. Evans, Dr. A. T. Fraser, Sir William Halcrow, Prof. F. L. Hopwood, Mr. L. B. W. Jolley, Mr. D. NorthallLaurie, Dr. E. Talbot Paris, Sir Harry Railing, Prof. D. V. Thompson, Prof. H. E. Watson.

\section{Physical Society : Election of Officers}

THE following have been elected officers for 194748 of the Physical Society : President, Prof. G. I. Finch; Vice-Presidents, Sir Edward Appleton, Mr. A. J. Philpot, Prof. H. R. Robinson, Dr. W. D. Wright; Hon. Secretaries, Dr. W. Jevons, Dr. H. H. Hopkins; Hon. Foreign Secretary, Prof. E. N. da C. Andrade; Hon. Treasurer, Dr. H. Shaw; Hon. Librarian, Dr. R. W. B. Pearse; Members of Council, Dr. W. S. Stiles, Dr. C. H. Collie, Prof. J. D. Bernal, Dr. D. Roaf, Dr. A. C. G. Menzies, Prof. R. E. Peierls, Dr. F. C. Toy, Prof. J. F. Allen, Mr. J. H. 
Awbery, Prof. L. F. Bates, Dr. R. C. Evans, Dr. C. E. Wynn-Williams.

The officers for 1947-48 of the four Groups of the Society are as follows: Colour Group: Chairman, Mr. J. G. Holmes; Hon. Secretary, Dr. W. D. Wright; Optical Group: Chairman, Prof. L. C. Martin; Hon. Secretary, Mr. E. W. H. Selwyn; Low-Temperature Group: Chairman, Sir Alfred Egerton; Hon. Secretary, Mr. G. G. Haselden; Acoustics Group: Chairman, Mr. H. L. Kirke; Hon. Secretaries, Mr. W. H. Allen and Mr. A. T. Pickles.

\section{University of Glasgow: Appointments}

THE following appointments in the University of Glasgow have been announced : Prof. G. W. Wishart, professor of physiological chemistry, is to become director of post-graduate medical education. Mr. J. R. Anderson has been appointed lecturer in pathology ; Dr. W. F. Anderson, lecturer in materia medica; Dr. J. C. D. Brand (of King's College, London), lecturer in chemistry; Dr. S. A. Hutchinson (formerly with the Distillers' Co., Ltd.), lecturer in botany; and Mr. A. C. Robb, Nuffield research assistant in physics.

\section{Congresses}

International Conference on the Emission from the Aurora and the Night Sky

AN international conference to discuss the emission from the aurora and the night sky is being arranged under the auspices of the Gassiot Committee of the Royal Society. This will be held in London during July $7-11$ at the rooms of the Royal Society at Burlington House.

\section{Conference on the Strength of Solids}

A DETAILED programme has now been prepared of the Conference on the Strength of Solids to be held at the H. H. Wills Physical Laboratory, University of Bristol, during July 7-10 (see Nature, Feb. 8, p. 193). The topics to be discussed include hardening of metals by internal oxidation (J. L. Meyering, Eindhoven), rate of approach to the ordered state in alloys (M. Weil, Grenoble), mechanical properties of metals at low temperatures (Prof. M. J. Druyvesteyn, Delft), creep in metals (Prof. E. N. da C. Andrade, Dr. E. Orowan and Dr. B. Chalmers), recovery and recrystallization (Prof. W. G. Burgers, Delft), hardness and crystal size (Sir Lawrence Bragg), thermo-electric methods of studying diffusion (C. Crussard, Paris), internal friction in metals (Prof. L. Guillet, Paris), elastic after-effects in iron (Prof. H. B. G. Casimir, Eindhoven) and sintered artefacts (J. H. McKee).

\section{Nuclear Physics in Biological and Medical Sciences}

THE University of California Medical School, in association with University Extension, University of California, has arranged a course in the application of nuclear physics to the biological and medical sciences. This course will be given at the Medical Center, San Francisco, during June 30-July 18. There will be lectures, laboratory demonstrations and seminars for round-table discussions. The course is open to those interested in the field of medical and biological research. The first week will be devoted to lectures, etc., on the general subject, the second week to the radioactive 'tracers' in biology and medicine and the third to therapeutic and diagnostic aspects of 'tracer' elements. Detailed information can be obtained from Dr. Stacy R. Mettier, head of the Postgraduate Instruction Medical Extension, University of California Medical Center, San Francisco 22, California.

\section{Industrial Utilization of Agricultural Products and of Seaweed}

A Colloquium on the Industrial Utilization of Agricultural Products and of Seaweed, arranged by the Irish Chemical Association and the Dublin Section of the Royal Institute of Chemistry, will be held in the Department of Chemistry, University College, Dublin, on July 2 and 3 . The meetings will be opened by the Minister for Industry and Commerce of Eire, and the first session will be a general survey opened by Prof. J. L. Simonsen, director of the Colonial Products Research Council, London, who will speak on "Agricultural Products and the Chemical Industry". The second session, on seaweed, will be opened by Prof. J. B. Speakman, professor of textile industries, University of Leeds, with a paper on "The Production, Properties and Uses of Seaweed Rayon". The third session will deal with carbohydrates, and will be opened by a paper by Prof. E. L. Hirst, Sir Samuel Hall professor of chemistry, University of Manchester, on "The Utilization of Carbohydrate Products". On July 3, there will be a Government reception at Phœnix Park, Dublin.

\section{Announcements}

Sir Robert Robinson, Waynflete professor of chemistry in the University of Oxford, and Prof. P. Karrer, professor of chemistry in the University of Zurich, have been elected Correspondants for the Section of Chemistry of the Paris Academy of Sciences. Sir Robert Robinson has also recently been elected a foreign member of the Royal Norwegian Academy of Sciences.

A conversazione of the Royal Society is being held at the Society's rooms on May 29 at 8.30 p.m.

Mr. J. Davidson PratT, director and secretary of the Association of British Chemical Manufacturers, has been awarded by the American Government the Medal of Freedom with silver palms for exceptionally meritorious work and co-operation with the United States while Controller of Chemical Defence Development at the Ministry of Supply during 1940-45.

THE Ministry of Supply announces the following appointments to the Minister's Advisory Council on Scientific Research and Technical Development: Prof. Wesley Austin, Goldsmith's professor of metallurgy in the University of Cambridge; Prof. W. E. Curtis, professor of physics at King's College, Newcastle; Lord Hankey; Prof. Willis Jackson, professor of electrical engineering at the Imperial College of Science and Technology, London; Prof. E. K. Rideal, Fullerian professor of chemistry at the Royal Institution; Mr. S. Robson, of the Imperial Smelting Corporation of Bristol.

Dr. E. C. Amoroso, reader in histology and embryology at the Royal Veterinary College, London, has been appointed to the chair of veterinary physiology in the College.

Erratum. In the communication "Phase-Contrast in the Photomicrography of Metals", in Nature, May 10, p. 639 , par. 6, for " $42-\mathrm{mm}$. oil immersion" read "2-mm. oil immersion". 